Asia Proceedings of Social Sciences

(APSS)

www.readersinsight.net/APSS

\title{
The Effect of Internal and External Factors on Tax Compliance in SMEs, Padang, Indonesia
}

\section{Musdalifah Dimuk}

Faculty of Business and Accountancy, Universiti Selangor

Malaysia

\section{Zulher}

Departement of Management, STIE Bangkinang Indonesia

\section{Suarni Norawati}

Departement of Management, STIE Bangkinang Indonesia

\section{Muhammad Rivandi}

Sekolah Tinggi Ilmu Ekonomi-KBP, Padang, Indonesia

\section{Popi Fauziati ${ }^{\star}$}

Faculty of Business and Accountancy, Universiti Selangor, Malaysia

Accounting Departement, Faculty of Economics, Universitas Bung Hatta Indonesia

*Corrosponding author's Email: popifauziati@bunghatta.ac.id

Peer-review under responsibility of $4^{\text {th }}$ Asia International Conference 2018 editorial board (http://www.utm.my/asia/our-team/) (C) 2018 Published by Readers Insight Publisher, lat 306 Savoy Residencia, Block 3 F11/1,44000 Islamabad. Pakistan, info@ readersinsight.net 


\section{Research High Iight s}

Taxpayer compliance can be influenced by internal factors and external factors. Internal factors are factors that originate from within the taxpayer themselves and relate to individual characteristics that trigger the implementation of tax obligations. External factors are factors that come from outside of the taxpayer, such as the situation and circumstances surrounding the taxpayer. This study proposed the influence of internal factors and external factors on tax compliance. There are 2 hypotheses tested and the results show that business characteristics and owner characteristics have no significant effect on tax compliance in SME, Padang, Indonesia.

\section{Research Objectives}

The research objectives are: knowledge and tax on compliance. Previous studies show the age, sector, size, education and knowledge influence tax compliance. Kurniati (2011) age has a positive and significant effect on tax compliance, Haseldine and Hansdford (2002) business sector has a significant effect on tax compliance and Suryadi (2006) measure has a significant effect on tax compliance. Education and tax knowledge have a positive and significant effect on tax compliance (Tyas, 2013; Pratiwi, 2015).

\section{Methodology}

\section{Top of Form}

The sampling technique in this study is Simple Random Sampling, which is taking samples from the population randomly carried out regardless of the strata that exist in that population. The sample in this study was SMEs in the city of Padang. Variable measurements using Pratama (2012) and Smulders (2016) adopted questionnaires. The age, sector, size, and education are measured using a nominal scale. Tax knowledge and tax compliance are measured by a 5-point Likert scale. Hypothesis testing is done using multiple regression. 


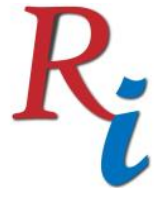

\section{Asia Proceedings of Social Sciences \\ (APSS) \\ www.readersinsight.net/APSS}

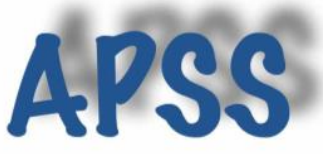

\section{Results}

The number of questionnaires distributed was 100 questionnaires and the return of 89 questionnaires (89\%). Means 11 questionnaires (11\%) that did not return. This is because the time for distributing questionnaires is incorrect, so that the returned questionnaires can be processed as many as 89 questionnaires (89\%). The description of the respondents' characteristics shows that the age of the largest company at the age of the company> 5 years is 59 companies. The majority of respondent's education was in public high schools with 45 respondents. The largest company income in the group $<50$ million rupiah as many as 37 companies. The business sector that dominates research is the trade sector and the majority of owners do not have accounting knowledge. From the results of testing the hypotheses obtained results of business characteristics and owner characteristics do not have a significant effect on tax compliance.

\section{Findings}

Business life does not have a significant effect on tax compliance. This is because business age is not compliant in paying taxation, even though the company has just been established or the business has been running for a long time but the owner is not obedient in paying taxes. The business sector in SMEs are many in various fields but do not obey their obligation to pay taxes. The size of the business in the SMEs is often not obeying the obligation to pay taxes, even though the revenue is higher every year but does not carry out the obligation to pay taxes. The education level of the owner does not guarantee compliance in paying the tax on his business and the presence or absence of taxpayers has an understanding of the tax also does not affect its compliance.

\section{References}

Hasseldine,J., \& Hansford, A. (2002). The compliance burden of VAT : Further evidence from the UK. Australian Tax Forum, 17(4):369-388. 


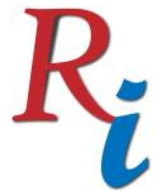

\section{Asia Proceedings of Social Sciences \\ (APSS) \\ www.readersinsight.net/APSS}

Kurniati, A. (2011). Analisis Pengaruh Sosialisasi, Sanksi Dan Faktor-Faktor Demografi Terhadap Kepatuhan Wajib Pajak PBB DiSurakarta. Jurnal Bisnis Ekonomi. 15 (2).

Pratama, M.,R. (2012). Analisis Faktor-Faktor Yang Mempengaruhi Kesadaran Wajib Pajak Orang Pribadi Terhadap Kepatuhan Kewajiban Perpajakan Di Kota Tangerang Selatan. Skripsi. Universitas Bina Nusantara.

Pratiwi, P., S. (2015). Pengaruh Pemahaman Peraturan, Administrasi dan Sanksi Perpajakan Pada Kepatuhan Wajib Pajak Hotel di Kota Denpasar. Skripsi. Sarjana Fakultas Ekonomi dan Bisnis Universitas Udayana.

Smulders,S.,Stiglingh,M.,Franzsenn, R., \& Fletcher, L. (2016). Determinants of external tax compliance costs: Evidence from South Africa. South African Journal of Accounting Research, DOI: 10.1080/10291954.2016.1160175

Suryadi.(2006).Model hubungan Kausal kesadaran,Pelayanan,Kepatuhan Wajib Pajak dan Pengaruhnya terhadap Kinerja Penerimaan Pajak; Suatu survey di Wilayah Jawa Timur, Jurnal Keuangan Publik, 4 (1).

Tyas, I., W. (2013). PengaruhUmur, Pendidikan, Penghasilan Bruto dan Moral Terhadap Kepatuhan Pembayaran Pajak. Jakarta :Skripsi. Sekolah Tinggi Ilmu Ekonomi Setia Budi Jakarta. 